\title{
DZIALALNOŚĆ IWANA KEDRYNA RUDNICKIEGO NA RZECZ POROZUMIENIA UKRAIŃSKO-POLSKIEGO LAT 30. XX WIEKU W II RP
}

\author{
SYLWIA WÓJTOWICZ \\ Uniwersytet Wrocławski, Wrocław — Polska \\ ДІЯЛЬНІСТЬ ІВАНА КЕДРИНА РУДНИЦЬКОГО В СПРАВІ УКРАЇНСЬКО- \\ ПОЛЬСЬКОГО ВЗАСМОРОЗУМІННЯ В 30-ИХ РОКАХ ХХ СТОЛІТТЯ В РП \\ СИЛЬВІЯ ВУЙТОВИЧ \\ Вроцлавський університет, Вроцлав - Польща
}

АНОТАЦІЯ. У статті досліджено діяльність Івана Кедрина Рудницького - українського письменника й політика міжвоєнного періоду Як член UNDO (Українського національного демократичного об’єднання) та журналіст газети „Діло” І. Рудницький захищав інтереси українців, які проживали в II Речі Посполитій (РП). У перш. пол. 30-х років він став одним з аніматорів політики нормалізації складних польсько-українських відносин.

\author{
KEDRYN RUDNICKI'S ACTIVITY IN THE FIELD \\ OF UKRAINIAN-POLISH MUTUAL UNDERSTANDING \\ IN THE 30s OF THE XX ${ }^{\text {th }}$ CENTURY \\ IN THE POLISH-LITHUANIAN COMMONWEALTH
}

SYLVIA VUITOVICH

Wroclaw University, Wroclaw — Poland

\begin{abstract}
In the article the activities of the Ukrainian writer and politician of the interwar period Ivan Kedryn Rudnicki are discussed. As a member of UNDO (Ukrainian National Democratic Alliance) and journalist of the newspaper "The Dilo" Rudnicki stood on guard of the interests of the Ukrainians, living in the Second Polish Republic. In the first half of the 30 s he was one of the animators of standardization policy in very difficult PolishUkrainian relations.
\end{abstract}

$\mathrm{W}$ spółcześni autorzy piszący na temat stosunków polsko-ukraińskich w ogóle, a na temat pierwszych dekad XX stulecia w szczególności, mimo rozbieżności dotyczących interpretacji poszczególnych faktów, niemal zawsze zgodni są co do tego, że były to kontakty bardzo trudne, którym zarówno historiografia polska, jak i ukraińska poświęcała zbyt mało rzeczowej i obiektywnej uwagi, przez co zagadnienie relacji polsko-ukraińskich obrosło wieloma mitami i negatywnymi stereotypami. Ich obecność w mentalności obydwu narodów w okresie konfliktów przyczyniała się do jeszcze większego zaogniania problemów, w okresie pokoju do braku chęci podejmowania konstruktywnego dialogu. Warto bowiem pamiętać, że na wspomniane w tytule niniejszego artykułu pierwsze dekady XX wieku przypadał czas walk ukraińsko-polskich o własną państwowość, a po upadku Zachodnio-Ukraińskiej Republiki Ludowej w 1919 roku i oficjalnej przegranej Ukra- 
ińców galicyjskich, którą ostatecznie przypieczętowała decyzja Rady Ambasadorów z 14 marca 1923 roku — czas żmudnych, niejednokrotnie desperacko-rozpaczliwych działań społeczeństwa ukraińskiego na rzecz wypracowania możliwie najlepszych warunków funkcjonowania w ramach II Rzeczpospolitej - młodym państwie targanym trudnościami narastającymi tak wewnątrz kraju, jak i poza jego granicami ${ }^{1}$. Istotnym czynnikiem kształtującym polską politykę narodowościowa, a co za tym idzie także zagraniczną, był problemem walki o granice państwa, a później ciaggego potwierdzania ich status quo. Konflikt polsko-ukraiński w tej sprawie był najwcześniejszym, najdłużej trwającym i najbardziej krwawym konfliktem II RP². Ukraińcy bowiem, mimo ponoszonych porażek nie chcieli rezygnować z realizacji marzeń o własnym państwie i wyraźnie manifestowali swoją niechęć do polskiej administracji państwowej, która wprowadzana była w województwach południowo-wschodnich bardziej drogą nieudolnej improwizacji aniżeli odpowiednio przygotowanego planu. Rozognione podczas wojny nastroje w zderzeniu z nieprzyjaznym aparatem państwa w pierwszej dekadzie jego istnienia regularnie przeradzały się w protest, bojkot i sabotaż. Postawę negacji początkowo prezentowały niemal wszystkie ukraińskie środowiska polityczne: od konserwatystów po nacjonalistów. Jednak z czasem zaczęto dostrzegać, że niechęć do nowej administracji nie może być jedynym czynnikiem konsolidującym ukraińskie środowisko polityczne, w łonie którego dość szybko zaczęły uwidaczniać się podziały i konflikty. Wkrótce więc znalazło się kilku polityków narodowych, którzy doszli do wniosku, że długotrwała polityka negacji jest szkodliwa dla sprawy ukraińskiej (szczególnie po decyzji Rady Ambasadorów) i że w aktualnych warunkach zarówno wewnętrznych, jak i zewnętrznych kwestia powołania własnego państwa musi zostać odłożona na czas bardziej dogodny. Zaobserwowano też, że na fali niezadowolenia w społeczeństwie ukraińskim niebezpiecznie wzrastać zaczęly sympatie lewicowe i nacjonalistyczne. Nacjonaliści prezentowali niezmiennie wrogie nastawienie wobec II RP. Regularnie organizowali akcje dywersyjno-sabotażowe, na które władza polska zaczęła w końcu odpowiadać pacyfikacjami $^{3}$. Represje ze strony środowiska nacjonalistycznego czekały również polityków ukraińskich próbujących podejmować jakąkolwiek ugodę ze stroną polską ${ }^{4}$. Realną potrzebą była więc konsolidacja sił politycznych i współpraca ponad podziałami. W kręgach działaczy narodowych zaczęła krystalizować się myśl o utworzeniu stronnictwa politycznego, którego podstawą byłaby działalność oparta na demokratycznych zasadach. Jej realnym urzeczywistnieniem było powołanie w 1928 roku UNDO (Ukraińskiego Zjednoczenia Narodowo-Demokratycznego). Organizacja miała charakter narodowy, demokratyczny, ponadklasowy ${ }^{5}$. W skład UNDO weszli działacze

${ }^{1}$ W skład ówczesnej Polski weszły ziemie wschodnie z sześcioma województwami: Wileńskim, Nowogródzkim, Poleskim, Wołyńskim, Lwowskim, Tarnopolskim, Stanisławowskim, przy czym cztery ostanie uważane były przez władze polskie za tereny najgęściej zasiedlone przez ludność ukraińską. Granicę wschodnią II RP ustalił traktat ryski zawarty 18 marca 1921 roku między rządem polskim a rządem ZSRR. Traktat zatwierdził granicę przebiegającą mniej więcej w tym samym miejscu, w którym niegdyś przebiegała granica II rozbioru Polski.

${ }^{2}$ J. Kukułka, Francja a Polska po traktacie wersalskim 1919 - 1922, Warszawa 1970, s. 114.

${ }^{3}$ R. To m czyk, Ukraińskie Zjednoczenie Narodowo-Demokratyczne 1925-1939, Szczecin 2006, s. 17.

${ }^{4}$ Znany poeta z grupy „Mołoda Muza” i jednocześnie polityk z partii włościańskiej za lojalnościowe czy też, jak niektórzy mówili, polonofilskie działania został rozstrzelany przez UWO (Ukraińską Wojskową Organizację) w miejscowości Kamionka Stumiłowa. Jego nie mniej znany kolega „po piórze” i redaktor lwowskiego czasopisma „Ridnyj Kraj” za swoje ugodowe poglądy przez pierwsze lata II RP narażony był na krytykę i ostracyzm ze strony ukraińskiej elity w większości stojącej na stanowisku pronarodowym, a więc wykluczającej możliwość bliższej współpracy ze stroną polską.

${ }^{5}$ R. Tomczyk, Ibidem, s. 53. 
ze wszystkich stron narodowej sceny politycznej. W liberalnym skrzydle organizacji odnalazł swoje miejsce młody historyk, publicysta polityczny i dziennikarz lwowski Iwan Kedryn ${ }^{6}$ Rudnicki (1896-1995). Kreowany był na głównego ideologa partii, której powstanie, jak słusznie zauważył jeden ze współczesnych historyków polskich Ryszard Tomczyk, było bodajże najważniejszym wydarzeniem w politycznym legalnym życiu ukraińskiego społeczeństwa w Galicji Wschodniej okresu międzywojennego. ${ }^{7}$ Jednak atmosfera panująca w UNDO od początku jego istnienia daleka była od ideału. Konfliktogenny okazał się pluralizm ideologiczny oraz brak jednolitego poglądu na kwestię stosunków ukraińsko-polskich. Jednym z rzeczników weryfikacji dotychczasowej postawy negacyjnej wobec władz polskich był Rudnicki. Wywodził się z ze znanej rodziny ukraińskiej, w której płynęła także krew polska i żydowska. Ojciec Kedryna - Jan Rudnicki - ceniony w Galicji Wschodniej notariusz posiadał polsko-ukraińskie korzenie. Ożenił się z pochodzącą ze starego rodu Żydów galicyjskich Idą Szpigel, która przyjęła kulturę męża (na chrzcie otrzymała imię Olga) i wychowywała dzieci w poczuciu tożsamości ukraińskiej. W ukraińskim życiu publicznym, oprócz Iwana, zaistniało także jego starsze rodzeństwo: Mychajło Rudnicki (1889 - 1975) — znany ukraiński krytyk literacki i pisarz modernistyczny oraz Milena Rudnicka (1892 - 1976), która, podobnie jak Iwan Kedryn, zajmowała istotne miejsce na ukraińskiej scenie polityczno-społecznej okresu międzywojennego. Oboje byli aktywnymi działaczami politycznymi, przy czym Kedryn, w przeciwieństwie do swojej siostry, prezentującej zdecydowanie nieugiętą postawę wobec polskiego aparatu państwowego, wykazywał większą wolę łagodzenia polsko-ukraińskich konfliktów. Stąd też przewodnictwo UNDO powierzyło mu funkcję korespondenta prasowego przy Ukraińskiej Reprezentacji Parlamentarnej (URP) w Sejmie oraz łącznika UNDO do Jewhena Konowalca. Publicysta był też zwolennikiem zbliżenia UNR (Ukraińscy Ludowi Republikanie, tzw. Petlurowcy) do Zjednoczenia. Środowisko Petlurowców było mu szczególnie bliskie. W roku 1917 przebywał bowiem w Kijowie, zajmując posadę w państwowych strukturach oświatowych Ukraińskiej Republiki Ludowej a po zajęciu stolicy przez sowietów wstąpił do wojska i brał udział w walkach, za co został odznaczony Krzyżem Semena Petlury. Po powrocie do Galicji Wschodniej utrzymywał rozległe kontakty z polityczną i kulturalną elitą II RP. W swoich licznych wypowiedziach publicystycznych krytykował separatyzm galicyjski oraz, mimo bliskiej znajomości z Konowalcem, organizowane przez nacjonalistów działania terrorystyczne. Jednocześnie był ostrym recenzentem wielu decyzji polskich władz wobec Ukraińców. Po wojnie emigrował do Austrii, a następnie do USA, gdzie mieszkał do końca życia ${ }^{8}$.

Najbardziej wyraziste działania Kedryna na rzecz porozumienia ukraińsko-polskiego przypadają na rok 1930, który w pamięci historycznej większości Ukraińców zapisał się przede wszystkim jako czas głębokiego konfliktu polsko-ukraińskiego i pacyfikacji ludności ukraińskiej. W historiografii polskiej kojarzony jest z wydarzeniami brzeskimi ${ }^{9}$. W zastanej, bezwyjściowej jakby się wydawało, sytuacji naj-

${ }^{6}$ Kedryn to pseudonim przyjęty przez Rudnickiego podczas emigracji wiedeńskiej w latach 1920 - 1923.

7 Tomczyk, Ibidem, s. 53. Warto zauważyć, że po przystąpieniu do Zjednoczenia działaczy z Wołynia, organizacja miała możliwość wyłonienia własnej reprezentacji parlamentarnej i poszerzenia wpływów na ziemiach północno-wschodnich, słowem mogła zacząć realnie wpływać na położenie mniejszości ukraińskiej w ówczesnej Polsce.

${ }^{8}$ Zob.: R. Torzecki, Kwestia ukraińska w Polsce w latach 1923 - 1929, Kraków 1989, s. 365.

${ }^{9} \mathrm{~W}$ sierpniu Józef Piłsudski objął tekę premiera, prezydent Mościcki rozwiązał parlament, pozbawiając jego członków immunitetu, by bez większych kłopotów uwięzić w twierdzy brzeskiej przeciwnych obozowi sanacyjnemu działaczy z Centrolewu, a wraz z nimi kilku polityków UNDO wchodzących w skład URP. Ich aresztowanie było częścią szerzej zakrojonej odwetowej akcji pacyfikacyj- 
większym orężem okazała się z powodzeniem uprawiana przez niego publicystyka. W 1930 roku dziennikarz pełnił obowiązki redaktora naczelnego redakcji „Diła”. Tymczasowo zastępował uwięzionego w twierdzy brzeskiej Wasyla Mudrego i pod jego nieobecność od 21 listopada do 3 grudnia opublikował cykl 10 artykułów poświęconych doświadczeniom Ukraińskiej Reprezentacji Parlamentarnej Sejmu II kadencji oraz jej aktualnym problemom po ,wyborach brzeskich”, nie omijając zagadnienia relacji ukraińsko-polskich. W rubryce zatytułowanej $W$ przededniu dziatalności nowej Ukraińskiej Reprezentacji Parlamentarnej dziennikarz podważył zasadność dotychczasowych metod działalności posłów ukraińskich, szczególnie politykę negacji państwowości polskiej w istniejących warunkach politycznych. Głosił potrzebę zaprowadzenia polityki realizmu, która poprawiłaby położenie sprawy ukraińskiej. Wystąpienie Kedryna początkowo nie zostało entuzjastycznie przyjęte przez czołowych polityków ukraińskich, którzy po doświadczeniu dotkliwego aresztu z nieufnością odnosili się do podjęcia współpracy z aktualną ekipą rządzącą, dodatkowo bez wcześniejszych szczegółowych ustaleń w szeregach partii. Można się spodziewać, że kierownictwo UNDO, wyciągając wnioski z przeszłości, nie chciało też dawać pożywki środowisku nacjonalistycznemu. Wypowiedzi Kedryna oficjalnie więc uznane zostały za samowolę partyjną. Tak też ocenił postawę swojego zastępcy Wasyl Mudryj, który w latach następnych będzie zdeklarowanym i najbardziej wytrwałym rzecznikiem ukraińsko-polskiego porozumienia. Jednak tuż po powrocie z sześciotygodniowego więzienia napisał oficjalne sprostowanie zatytułowane: O pewnym cyklu artykułów $w$,Dile” , które opublikowane zostało w tymże czasopiśmie 18 grudnia 1930 r. Nie wchodząc w ocenę i analizę artykułów Kedryna, Mudryj w imieniu własnym, redakcji, URP oraz aktualnego kierownictwa UNDO odcią się od poglądów zawartych w omawianym cyklu i stwierdził, że są one tylko i wyłącznie spostrzeżeniami prywatnymi ich autora. Następne miesiące i lata pokazały, że to głos Kedryna rozpoczął nową pojednawczą tendencję w postawie politycznej części działaczy UNDO, która ostatecznie znalazła swoją realizację w roku $1935^{10}$.

Grunt pod oficjalne porozumienie z roku 1935 przygotowywany był od kilku lat także po stronie polskiej. Bezsprzecznie dużą rolę w tej materii odegrali publicyści polscy uprawiający, podobnie jak Kedryn, dziennikarstwo polityczne. Reprezentowali zazwyczaj obóz konserwatywny i propagowali ideę dialogu polsko-ukraińskiego, krytycznie odnosząc się do programu polityki narodowościowej głoszonego przez Narodową Demokrację, który z początkiem lat 30. XX w. stał się w Polsce programem dominującym ${ }^{11}$. Głos w kwestii ukraińskiej zabierali wybitni znawcy pro-

nej wobec społeczności ukraińskiej po działaniach sabotażowych UWO. Podczas pacyfikacji mieli zostać uwięzieni najbardziej niebezpieczni dla interesu państwa przedstawiciele mniejszości ukraińskiej. Za takich władza sanacyjna uznała jednak nie tylko członków UWO, ale także animatorów polityki negacji, w tym najważniejszych działaczy Zjednoczenia m.in. Dmytra Łewyckiego, jego zastępcę Wasyla Mudrego oraz Włodzimierza Celewicza. Podzielili oni los, a w niektórych przypadkach także celę polityków polskich, m.in. Wincentego Witosa czy Adama Pragiera. Zob.: Українська Парламентарна Репрезентація у Варшаві, Матеріали про пацифікацію українського населення в Галичині (вирізки з газет, інформації, резолюції й ін.), ЦДІА України, м. Львів, фонд 392, опис 1, к. 128.

${ }^{10}$ I. Кедрин, Життя - Подї-Люди. Спомини і коментарі, Нью Йорк 1976, с. 247-267 .

${ }^{11} \mathrm{~W}$ latach 30. w ruchu narodowodemokratycznym akcent kładziono przede wszystkim na polski interes narodowy, był on nadrzędny w stosunku do państwa i kwestii społecznej. W tym kontekście narodowi demokraci za rzecz naturalną uznawali konflikty narodowościowe. Rolę właściwego suwerena w państwie przydzielali narodowi polskiemu, który miał być jedynym dysponentem zasobów gospodarczych kraju i dziedzictwa kulturowego. Pozostałe narodowości zamieszkujące kraj miały podporządkować się politycznej, ekonomicznej i kulturalnej dominacji Polaków. „Polska dla Polaków” — oto hasło przewodnie obozu endeckiego, wcielającego w życie ideę państwa narodowego. Zob.: A. Chojnowski, Koncepcje polityki narodowościowej w rzqdach polskich w latach 1918-1939, Wrocław 1979, s. 20. 
blemów narodowościowych m.in. Leon Wasilewski, bracia Adolf i Adam Bocheńscy, Władysław Bączkowski, Stanisław Paprocki, Mieczysław i Ksawery Pruszyńscy, Piotr Dunin Borkowski, Marian Zdziechowski oraz Stanisław Łoś. Ich działalność spotykała się z wysoką oceną Iwana Kedryna podobnie, jak i większości działaczy UNDO. W 1933 roku dziennikarz ukraiński został zaproszony przez redaktora Bączkowskiego do współpracy w nowopowstałym czasopiśmie „Biuletyn Polsko-Ukraiński". Było to pierwsze w Polsce pismo polsko-ukraińskie, którego już sam tytuł zapowiadał ,porozumiewawczy" charakter ${ }^{12}$. Szybko stało się przeciwwagą dla wszystkich antyukraińskich pism polskich, przez Ukraińców zgodnie nazywanych „ukrainofobicznymi kurierkami”. Powstało z inspiracji II Oddziału Sztabu Głównego $\mathrm{z}$ zamysłem prowadzenia dialogu polsko-ukraińskiego, było też wspierane przez Wydział Narodowościowy MSW i Wydział Wschodni. Na jego łamach publikowali swoje teksty wspomniani publicyści polscy, ze strony ukraińskiej zaś, oprócz Kedryna, do współpracy zostali zaproszeni m.in. tacy intelektualiści, jak Roman Smal-Stocki, Jewhen Małaniuk, Myron Korduba, Włodzimierz Sołowij ${ }^{13}$. Niektórzy publicyści „Biuletynu...” byli członkami zorganizowanego 8 czerwca 1933 roku Towarzystwa Polsko-Ukraińskiego, które pełniło rolę bazy społecznej dla czasopisma ${ }^{14}$. Wielu z ukraińskich redaktorów pochodziło z tzw. wielkiej Ukrainy i niejednokrotnie, jak Kedryn, związani byli lub sympatyzowali z obozem petlurowskim. W swoim myśleniu o ukraińskości wychodzili więc poza galicyjski prowincjonalizm, poza pierwszą, jakby powiedział Bohdan Osadczuk, ,żelazną kurtynę" na Zbruczu ${ }^{15}$. Nie dziwi więc fakt, że dziennikarz ukraiński zaproszenie do współpracy z „Biuletynem...” chętnie przyjął, choć oczywiście nie bez uwag, co podkreślił już w tytule swojego pierwszego artykułu: Dwie uwagi ${ }^{16}$. Publicysta nie krył rezerwy wobec wszelkich inicjatyw próbujących wdrażać w życie „propagandę misji cywilizacyjnej na Wschodzie”. Doceniał jednak fakt, że, jak pisał: „Biuletyn Polsko-Ukraiński” jest niewątpliwie pierwszym tego rodzaju czasopismem polskim, poświęconym wyłącznie sprawom ukraińskim oraz stosunkom polsko-ukraińskim w ich najszerszym ujęciu. Stosunkowa śmiałość w traktowaniu poszczególnych tematów nastraja do szczerości $<\ldots .>{ }^{17}$

${ }^{12}$ Dotychczas dość konstruktywna dyskusja na temat kwestii ukraińskiej toczyła się przeważnie na łamach takich czasopism polskich, jak: „Wschód” Włodzimierza Bączkowskiego, „Bunt Młodych” (później „Polityka”), „Myśl Mocarstwowa” czy „Nasza Przyszłość”. Tematykę ukraińską podejmował także „Czas” i „Sprawy Narodowościowe”, pewne zainteresowanie tą kwestią przejawiało również „Słowo” wileńskie redagowane przez Stanisława Cata Mackiewicza, niekiedy „Robotnik” Mieczysława Niedziałkowskiego. Były to wydania stojące w opozycji wobec czasopism negatywnie ustosunkowanych do zagadnienia ukraińskości, które dominowały na rynku wydawniczym II RP. Nie wdając się w ich wyliczanie, wystarczy wymienić takie tytuły, jak „Kurier Lwowski” czy wydawany w Krakowie „Ilustrowany Kurier Codzienny”, a więc czasopisma uznawane za trybuny endecji. Zob.: B. Osadczuk, Wyjatkowe zwycięstwo, [w:] Jerzy Giedroyc: kultura, polityka, wiek XX. Debaty i rozprawy, pod red. A. Mencwela, A. Kowalczyka, L. Szrugi, Z. Grębeckiej, Warszawa 2006, s. 43.

${ }^{13}$ Warto także wymienić takie ukraińskie postaci, jak: Stepan Baran, Pawło Łysjak, Pawło Kowżun, Serhij Chruckyj, Iwan Lipoweckyj, Andrij Żuk, Dmytro Doroszenko, Pawło Zajcew, Luka Luciw, Stepan Czarneckyj, Andrij Kryżaniwski, Wołodymyr Kubijowycz, Mykoła Dańko, Wołodymyr Sołowij i in.

${ }^{14}$ R. Tomczyk, Op. cit., s. 202.

${ }^{15}$ B. Osadczuk, Ibidem, s. 43. Osadczuk słusznie zauważał, że „w Polsce w dwudziestoleciu międzywojennym pisano i mówiono stosunkowo dużo o sprawach mniejszości narodowych, więc także o Galicji i o konfliktach polsko-ukraińskich, ale to, co się działo za Zbruczem nie obchodziło nikogo”. Wyjątkiem był właśnie „Biuletyn Polsko-Ukraiński”, niekiedy też pisma polskie współpracujące $\mathrm{z}$ intelektualistami ukraińskimi.

${ }^{16}$ „Dwie uwagi”.

17 I. Kedryn, Dwie uwagi. Przygotowanie psychologiczne czy fakty dokonane?-Ostrożnie z propaganda misji cywilizacyjnej na Wschodzie, „Biuletyn Polsko-Ukraiński” nr 2, 1933, s. 9. 
Od tego momentu z taką też szczerością cyklicznie głosił swoje poglądy na temat najnowszej historii stosunków polsko-ukraińskich, a także poddawał ocenie bieżące wydarzenia ${ }^{18}$. Szeroko omawianą przez niego była, wciąż żywa w owym czasie i bolesna dla społeczeństwa ukraińskiego, kwestia ekspedycji karnych z 1930 roku. Bezpośrednio po wydarzeniach publicysta wykazał dużą aktywność w przygotowywaniu materiałów dowodowych na temat pacyfikacji, które strona ukraińska w roku 1930 słała wraz ze skargami do Ligii Narodów. Nie wszyscy polscy komentatorzy polityczni wykazali zrozumienie dla tego typu działan. Stanisław Łoś, uznawany przez wielu za znawcę problematyki ukraińskiej w II RP, nie raz krytycznie odnosił się do sposobu, w jaki Ukraińcy prezentowali swoje racje wobec wydarzeń roku 1930 i podzielał opinię tej części polityków polskich, którzy uważali, że strona ukraińska mocno przejaskrawia fakty. ${ }^{19}$ Inni publicyści polscy z kręgu konserwatywnego nie prezentowali już tak rygorystycznej postawy wobec piśmiennictwa i działalność politycznej Kedryna. Wręcz odwrotnie, doceniali szczerość wypowiedzi i umożliwiali mu prezentację ukraińskiego punktu widzenia w sprawie wielu drażliwych kwestii dotyczących wspólnej historii, jak i wydarzeń bieżących. W ten sposób dziennikarz ukraiński mógł w „Biuletynie...” opublikować tekst pt. Eligiusz Niewiadomski $i$ Dmytro Danytysz ${ }^{20}$, w którym zaprezentował szerszej opinii publicznej argumenty podobne do tych, które URP zawarła w uzasadnieniu interpelacji złożonej w Sejmie tuż po pacyfikacji. Publicysta poddawał w wątpliwość zasadność używania środków przemocy w postaci ekspedycji karnych, które według niego uspokajają sytuację tylko na krótko i w dalszej perspektywie mają dalekosiężne, negatywne skutki. Sugerował, że autorami przeważającej części podpaleń nie byli Ukraińcy, a „najrozmaitsze elementy z ideą rewolucji ukraińskiej istotnie mało mające wspólnego"21. Przypominał stronie polskiej, że najbardziej opiniotwórcza gazeta ukraińska „Diło” potępiła podpalenia, pojawił się też wspólny komunikat trzech najważniejszych ukraińskich stronnictw politycznych z podpisami ich prezesów, gdzie ostro i jednoznacznie została osądzona akcja sabotażowa. A jednak władze zdecydowały się na pacyfikację, która wpłynęła na zasadniczą zmianę oceny państwa polskiego przez większość Ukraińców i raczej nie wywołała uczucia skruchy. Wręcz odwrotnie, wzbudziła poczucie krzywdy i chęć odwetu. Zastosowane wobec cywilnej ludności środki represji wywołały przerażenie społeczeństwa ukraińskiego. W atmosferze strachu i poniżenia Ukraińcy zaczęli odchodzić od krytyki taktyki obozu rewolucyjnego. Dziennikarz twierdził, że dopiero wówczas cały kraj i cały naród zespolił się z europejską oraz zamorską emigracją we wspólnym wysiłku dochodzenia swoich krzywd. Prestiż UWO (Ukraińskiej Organizacji Wojskowej) szybko więc został zrestytuowany. Wychodzące w tym czasie w Ameryce czasopisma ukraińskie publikowały długie li-

${ }^{18}$ Zob. m. in. artykuły: Istota traktatu ryskiego. Kilka uwag z okazji 12 rocznicy pokoju ryskiego („BPU”, 1932), Eligiusz Niewiadomski i Dmytro Danytysz („BPU” 1933), „Potrzeba nam partnera...” („BPU”, 1933), Wzajemna neutralizacja („BPU”, 1934), Niepodległość Polski a Ukraińcy („BPU”, 1935), O prawdę historycznq dla imienia Józefa Pitsudskiego („BPU”, 1935), Ewolucja stosunków polsko-ukraińskich, („BPU”, 1936), Kompleks rosyjski u Ukraińców (rusofilstwo polityczne - galicyjskie moskalofilstwo — „radianofilstwo”) („BPU”, 1937), Pro domo sua oraz Dlaczego tak się dzieje („BPU”, 1938).

${ }_{19}$ Zob.: St. Łoś, Sprawa ukraińska, wybór tekstów pod red. M. Marszała i S. Wójtowicz, Kraków 2012, s. 175.

${ }^{20}$ I. K. Kedryn, Eligiusz Niewiadomski i Dmytro Danytysz, „BPU” 1933, s. 15-16.

${ }^{21}$ Ibidem, Kedryn dowodził, iż Ukraińcy szybko mieli dojść do wniosku, że w ten sposób przyczyniają się tylko do wypłacania dziedzicom niemałych odszkodowań i rozkwitu interesu premiowoasekuracyjnego. Nie mieli także celu w tym, aby prowokować władze do represji w okresie przedwyborczym. Szybko zaczęli odnosić się z niechęcią do akcji sabotażowych i nie zabrakło głosów, że podpalenia tylko kompromitują ideę rewolucji. 
sty datków zbieranych na cele UWO, gwałtownie zwiększoną aktywnością wykazała się także ukraińska emigracja polityczna w Europie. Wielu ówczesnych ukraińskich komentatorów sytuacji po pacyfikacyjnej w Galicji Wschodniej jednoznacznie podkreślało, pomijając już aspekt moralny i humanitarny całej akcji, że była ona największym błędem politycznym w polityce narodowościowej II RP $i$ dalekosiężną klęską w stosunkach polsko-ukraińskich.

Zgoła inny pogląd na bieżące wydarzenia prezentował rząd. Władze zdawały sobie sprawę, że po decyzji Rady Ambasadorów pacyfikacja była kolejnym mocnym ciosem, który załamał stronę ukraińską, co było zamierzonym efektem. Ukraińcy zmuszeni zostali do weryfikacji swojego stanowiska wobec państwa polskiego i zrozumieli, że dalsze utrzymywanie polityki opartej na zasadach sprzed $1930 \mathrm{roku}$, tj. na polityce negacji, prowadzi społeczeństwo ukraińskie do fizycznego zniszczenia. Strona polska chętnie posługiwała się cytatem z ukraińskiego czasopisma „Meta”, że „pacyfikacja pokazała przed narodem przez jedną chwilę zarys przepaści...” i, jak przekonywali zwolennicy działań pacyfikacyjnych, tylko w takiej sytuacji w polityce ukraińskiej mogły zwyciężyć głosy mówiące o potrzebie szukania porozumienia z władzą. ${ }^{22}$ Istotnie, Ukraińcy wyszli z ofertą odprężenia stosunków ukraińsko-polskich, a czynniki rządowe cieszyły się „,spokojnym” tonem ...., lecz radość władz $\mathrm{z}$ obrotu wydarzeń była przedwczesna ${ }^{23}$ - dowodził Kedryn. Akty terrorystyczne przeprowadzane $\mathrm{w}$ kolejnych miesiącach i latach przez podziemie ukraińskie potwierdziły słuszność jego poglądu. Refleksje na ten temat zawarł w artykule zatytułowanym Radykalizacja nastrojów i prasa, który ukazał się w 1931 r. w ukraińskiej gazecie „Meta”. Dziennikarz dostrzegał, że brak chęci realnego porozumienia między dwiema stronami, prześciganie się w zarzutach i argumentach świadczących o słuszności własnej racji oraz brak jednolitego frontu politycznego wobec zastanych faktów zarówno po stronie polskiej, jak i ukraińskiej, wszystko to przyczyniało się do wzrostu sił ekstremistycznych sukcesywnie wcielających w życie ideę walczącego nacjonalizmu czy też bolszewizmu.

W podsycaniu radykalnych nastrojów nie małą rolę odgrywała również nieodpowiedzialna prasa. Jeszcze w 1931 roku, kiedy to nasiliły się działania OUN (Organizacji Nacjonalistów Ukraińskich) Iwan Kedryn wskazał trzy istotne czynniki, które przyczyniały się do radykalizacji poglądów i działań jego rodaków, a które można byłoby odnieść także do społeczeństwa polskiego. Czynnikiem obiektywnym było z pewnością obniżenie standardu życia wszystkich obywateli kraju. Lawina światowego kryzysu gospodarczego dotknęła również Polskę. Obok czynnika obiektywnego Kedryn wskazywał na niezadowolenie związane z pamięcią o niedawnych pomyłkach i zmarnowanych szansach historycznych. Najistotniejszym zaś była rozrastająca się do absurdalnych rozmiarów demagogia uprawiana na łamach prasy niemal wszystkich opcji politycznych. „Brak poczucia odpowiedzialności prasy różnych kierunków polega na tym, że nie zdaje ona sobie sprawy z tego, jakie mogą być ostateczne konsekwencje prowadzonej par force radykalizacji nastrojów, czym się to wszystko może skończyć i kto może z tego mieć korzyść" ${ }^{24}$. Bacznie przyglądając się ukraińsko-polskim stosunkom, publicysta dostrzegał także błędy w działaniu polityków ukraińskich. $Z$ czasem zaczął twierdzić, że wygłaszanie w sejmie polskim ostrych, opozycyjnych przemówien oraz niekończące się skargi i petycje słane przez Ukraińców za granicę nie przynoszą pożądanych efektów. Dają bowiem pole z jed-

${ }^{22}$ Archiwum akt nowych, MSW, syg. 1042, k. 3,4.

${ }^{23}$ I. Kedryn, Ibidem.

${ }^{24}$ I. Кедрин, Радикалізація настроїв і преса, Мета 1931, ч. 18, с. 1. 
nej strony dla radykalnych działań OUN, a z drugiej, dla represji administracyjnych wobec całego społeczeństwa ukraińskiego w Galicji25.

Kontakty Kedryna z przedstawicielami polskiego obozu zachowawczego nie ograniczały się tylko do działalności publicystycznej. Polityk zainteresowany był również utrzymywaniem dobrych relacji z konserwatystami pochodzącymi z Galicji, którzy nie podzielali kierunku politycznego wytyczanego przez Warszawę. Wielu z nich miało pochodzenie szlacheckie i postrzegało Galicję nie jako kolonię, ale jako kraj rodzinny, w którym od wieków żyli w zgodzie z miejscową chłopską ludnościa, i która w przeważającej większości była pochodzenia ukraińskiego. Uważali, że aktualna antyukraińska polityka Warszawy narusza wypracowane $\mathrm{z}$ dawien relacje i nastraja buntowniczo wieś ukraińską wobec polskich właścicieli ziemskich. Szczególnie negatywnie oceniano przysyłanie do Galicji kolonistów polskich, tzw. mazurów, uznawanych za „najgorszy element” z Galicji Zachodniej, który nie potrafił uprawiać roli. Nieumiejętna polityka ekonomiczno-gospodarcza państwa wobec Galicji Wschodniej sprzyjała nastrojom antypolskim i popychała konserwatywnych dotychczas Ukraińców w stronę ruchów rewolucyjnych. Dlatego polscy konserwatyści uznali, że należy szukać porozumienia z miejscowymi Ukraińcami i budować z nimi taki wspólny front, z którym koła rządowe, nierozumiejące polsko-ukraińskich relacji, musiałyby się liczyć. Wychodząc z powyższego założenia, zaczęto organizować spotkania polskiej arystokracji z przedstawicielami umiarkowanego skrzydła w UNDO, zwłaszcza tymi, którzy zajmowali się sprawami gospodarczymi i byli najbardziej zainteresowani zastopowaniem działań kolonizacyjnych. Z ostrą krytyką wobec tej inicjatywy, wedle zasady negacji wszystkiego, co polskie, wystąpili ukraińscy nacjonaliści, nazywając spotkania „,zarnymi kawami”, podczas których, jak uważano, ,undowcy” mieli sprzedawać ziemię ukraińską polskim panom. Do polsko-ukraińskich spotkań negatywnie odnosili się również przedstawiciele radykalnej frakcji Zjednoczenia, m.in. Milena Rudnicka, która konsekwentnie twierdziła, iż w represyjnym systemie II RP jakiekolwiek próby porozumienia dają złudny obraz polepszenia stosunków polsko-ukraińskich, osłabiając siłę argumentów ukraińskich zarówno w kraju, jak i za granicą ${ }^{26}$. Kedryn nie podzielał jednak poglądu swojej siostry i podczas „,czarnych kaw” reprezentował środowisko ukraińskie obok Dmytra Łewyckiego, Ostapa Łuckiego, Juliana Pawłykowskiego, Wołodymyra Kuźmowycza, Jewhena Chrapływego oraz kilku innych działaczy ukraińskich, którzy żywo zainteresowani byli gospodarczymi zmianami w regionie. Ze strony polskiej w spotkaniach uczestniczyli m. in.: hr Gołuchowski, Dzieduszycki, Dunin-Borkowski, bracia Bocheńscy oraz niektórzy posłowie i senatorowie z obozu demokratycznego. Po latach Kedryn ocenił, że spotkania nie miały większego znaczenia politycznego, nie brały w nich udziału postaci realnie wpływające na kurs polityki państwa, jednak, jak pisał we wspomnieniach, miały dużą wartość poznawczą, bowiem pozwalały stronom lepiej ocenić aktualną sytuację polityczną, poznać bliżej wzajemne poglądy i sposób myślenia ${ }^{27}$.

Na pierwszy znaczący efekt wszystkich działań zmierzających do porozumienia obu stron przyszło czekać do połowy 1935 roku. Kilka miesięcy przed tym w środowisku ukraińskim pojawiły się dwie koncepcje nawiązania konstruktywnej współpracy z Polakami. Pierwsza, której zwolennikiem był lider UNDO Dmytro Łewicki, widziała szansę współpracy z polską opozycyjną lewicą demokratyczną. Jej liderem był wówczas Stanisław Thugut. Druga, mówiła o poszukiwaniu nici porozumienia

${ }^{25}$ І. Кедрин, Життя -Подї-Люди..., с. 252.

26 Див.: М. Рудницька, Статmі, Листи, Документи, ред. М. Богачевська-Хомяк, М. Дядюк, Я. Пеленський, Львів 1998.

${ }^{27}$ І. Кедрин, Життя - Подї-Люди..., с. 158-159. 
z rządem. Iwan Kedryn będąc w dobrych osobistych kontaktach z Thugutem, został poproszony przez Dmytra Łewickiego o przeprowadzenie wstępnych rozmów dotyczących nawiązania bliższej współpracy ${ }^{28}$. Po odpowiednich konsultacjach doszło w końcu do konstruktywnego spotkania delegacji ukraińskiej z ministrem spraw wewnętrznych Marianem Zyndramem Kościałkowskim. Podczas audiencji ustalono kilka istotnych kwestii, realizacja których miała zapewnić w niedalekiej przyszłości zgodne współistnienia obu narodów w ramach państwa polskiego. Od tego dnia, tj. 29 maja 1935 r., jak pisał I. Kedryn, należy datować nową tendencję w kontaktach ukraińsko-polskich, nazywaną w historii obu narodów ,normalizacją” stosunków polsko-ukraińskich ${ }^{29}$.

Normalizacyjne ustalenia nie przetrwały próby czasu. Były jednak ważną, choć przez wiele lat historii powojennej zapomnianą cezurą w historii niełatwych relacji polsko-ukraińskich pierwszych dekad XX wieku. Aktywność bohaterów tamtych wydarzeń warta jest więc przypominania, nawet jeśli, tak jak Iwan Kedryn, nie odgrywali pierwszoplanowej roli w wyżej wymienionych ,porozumiewawczych” działaniach. Nie ulega wattpliwości jednak, że bez udziału osób z drugiego planu wielkiej polityki dojście do etapu normalizacji stosunków obu narodów nie byłoby możliwe. Warto też docenić siłę publicystki, która w międzywojniu w kwestii stosunków polsko-ukraińskich wspierała czy wręcz zastępowała instytucje zajmujące się sprawami mniejszości ukraińskiej. Zagadnienie ukraińskości w Polsce tamtego czasu nie było, jak wiadomo, przedmiotem rozważań na poziomie instytucjonalnym. Ukraińskość przez pierwsze lata II RP nie była traktowana jako osobna kwestia, którą należało rozwiązać, była postrzegana jako problemem, który należało zlikwidować. Nie przywiązywano więc wielkiej wagi do utworzenia osobnego ośrodka, który posiadałby odpowiednie zaplecze intelektualne i warsztatowe do prowadzenia systematycznych i kompleksowych studiów ukrainoznawczych. Istotną rolę w tym względzie odgrywało więc dziennikarstwo polityczne, w tym publicystyka wychodząca spod pióra Iwa Kedryna. Jako stały współpracownik „Biuletynu Polsko-Uraińskiego” napisał wszakże wiele artykułów ukazujących ukraiński sposób widzenia bieżących wydarzeń czy też istotnych kwestii w poszukiwaniu dróg porozumienia. Niejednokrotnie poddawał krytyce politykę poszczególnych rządów wobec mniejszości ukraińskiej, polemizował z prasą antyukraińską, pozytywnie jednak odnosił się do kultury polskiej. Ubolewał, że poglądy publicystów polskich, rozpatrujących kwestię ukraińską w sposób konstruktywny, nie przebijały się do szerokiej świadomości społeczeństwa polskiego, ignorowane były również przez czynniki rządowe. To dlatego Polska lat międzywojennych, jak twierdził swoich wspomnieniach, nawiązując do nierozstrzygniętego problemu używania terminów „Ukrainiec” i ,Rusin”, do końca istnienia nie wiedziała, jak właściwie nazywała się zamieszkująca ją największa, kilkumilionowa mniejszość narodowa ${ }^{30}$.

${ }^{28}$ Tughut jednak miał stwierdzić, że lewica demokratyczna jest w sejmie bezsilna, a jawna współpraca z Ukraińcami dodatkowo osłabi jej pozycję, dając przyczynek hurra-patriotycznej prasie i organizacjom polskim do większej nagonki na obie strony. Dlatego doradzał, aby zwrócić się z propozycją poszukiwania kompromisu do kół rządowych, które powoli również dojrzewały do poglądu, że niezbędna jest weryfikacja polityki państwa wobec mniejszości ukraińskiej. Dalsza inicjatywa przeszła w ręce znanego działacza UNDO Ostapa Łuckiego - pomysłodawcy wprowadzenia do aktualnego dyskursu politycznego terminu „,normalizacja”. Łucki zwrócił się do przebywającego od lat w Warszawie zdeklarowanego rzecznika porozumienia ukraińsko-polskiego prof. Romana Smal-Stockiego z prośbą o rozmowę z ministrem spraw wewnętrznych Marianem Zyndramem Kościałowskim. Na audiencji u ministra Smal-Stocki spytał wprost czy jest możliwa normalizacja stosunku władzy do mniejszości ukraińskiej. Zob.: I. Кедрин, Життя-Подї-Люди..., с. 252-253.

${ }^{29}$ Ibidem.

${ }^{30}$ Ibidem, c. 248. 